\title{
Experimental colonization of new habitats by Galba truncatula O.F. Müller (Gastropoda : Lymnaeidae) in central France and their susceptibility to experimental infection with the trematode Fasciola hepatica $\mathbf{L}$.
}

\author{
C. Vareille-Morel ${ }^{1}$ \\ D. Rondelaud ${ }^{2}$ \\ G. Dreyfuss ${ }^{3}$
}

Keywords : Galba truncatula, Fasciola hepatica, Zonitoides nitidus, colonization, experimental infections, habitats, populations.

Experimental introductions of Galba truncatula in new habitats were carried out over the 30 last years in the department of Haute-Vienne (central France) to study the details of snail settlement and the outcome of these populations, and to determine if the susceptibility of these new colonies to experimental infection with Fasciola hepatica did not change over time. A total of 51 samples (100 adult snails each) were collected from three populations known for their high susceptibility to $F$. hepatica infections $(>60 \%)$. Each sample was introduced in March in an open drainage furrow ( 36 meadows) or a road ditch (15 sites). which had never been inhabited by snails. Introduced snails from 22 samples survived in 9 furrows and 13 road ditches. In these sites, the number of overwintering $G$. truncatula increased up to the-second or third year post-introduction and progressively decreased in the following years to become stable from the sixth or seventh year (less than 40 snails per site). In 13 populations (out of 22), experimental infections of snails with $F$. hepatica did not result in significant variations in survival rates or in prevalences of infections when compared to the respective rates recorded in the three original populations. Conversely, in the nine other populations, experimental infections of snails resulted in a decrease in prevalence $(<40 \%)$, whereas the survival rates of snails at day 30 post-exposure did not change. This last result might be explained by a change in natural parasite pressure in the new habitats, being probably lower than that existing in the three sites inhabited by the populations of origin.

Colonisation expérimentale de nouveaux habitats par Galba truncatula O.F. Müller (Gastéropodes : Lymnaeidae) dans le centre de la France et leur sensibilité à l'infestation expérimentale avec le trématode Fasciola hepatica $\mathrm{L}$.

Mots-clés : Galba truncatula, Fasciola hepatica, Zonitoides nitidus, colonisation, infestations expérimentales, habitats, populations.

Des introductions expérimentales de Galba truncatula dans de nouveaux habitats ont été réalisées au cours des 30 dernières années dans le département de la Haute-Vienne (France centrale) pour étudier le détail de leur installation, leur devenir, et pour déterminer si la sensibilité de ces nouvelles colonies à l'infestation expérimentale avec Fasciola hepatica ne change pas dans le temps. Un total de 51 échantillons, comprenant chacun 100 mollusques adultes, ont été prélevés dans trois populations connues pour leur haute sensibilité à l'infestation fasciolienne $(>60 \%)$. Ils ont été introduits en mars dans une rigole de drainage superficielle ( 36 prairies) ou un fossé de route (15 sites) dépourvus de limnées depuis longtemps. Les mollusques introduits (22 échantillons) ont survécu dans 9 rigoles et 13 fossés de route. Dans ces sites, le nombre de G. truncatula transhivernantes s'est accru jusqu'à la deuxième ou troisième année post-introduction et a diminué progressivement au cours des années suivantes pour devenir stable à partir de la sixième ou septième année (moins de 40 limnées par site). Dans 13 colonies (sur 22), des infestations expérimentales avec $F$. hepatica ne montrent pas de variation significative dans les taux de survie ou les prévalences lors-

1. UPRES-EA $n^{\circ}$ 3174, Faculté des Sciences, 123 avenue Albert Thomas, 87060 Limoges France.

2. Faculté de Médecine, 2 rue du Docteur Raymond Marcland, 87025 Limoges Cedex, France. Correspondent author.

3. Faculté de Pharmacie, same address. 
qu'on les compare avec les trois populations d'origine. Dans les neuf autres colonies, les infestations expérimentales se traduisent par une chute dans les prévalences $(<40 \%)$ alors que les taux de survie au $30^{\mathrm{e}}$ jour post-exposition ne changent pas. Ce dernier résultat peut s'expliquer par un changement dans la pression parasitaire naturelle sur ces nouveaux habitats, celle-ci êtant probablement plus faible que celle existant dans les trois sites colonisés par les populations d'origine.

\section{Introduction}

Zonitoides nitidus O:F. Müller (Gastropoda : Gastrodontidae) is known to be malacophagous in June-July and to feed on the freshwater snails which live with it in the swampy meadows on acid soils. Owing to its ability, Z. nitidus was proposed to control a freshwater snail : Galba truncatula O.F. Müller, in its habitats and numerous studies were performed by our team between 1975 and 1988 to analyze the effects of this predator on lymnaeid populations (Rondelaud 1975; 1981, for example).

Experimental introductions of $G$. truncatula in new habitats were carried out over the 30 last years in the department of Haute-Vienne (central France) to have snails available for laboratory studies on the predation of $Z$. nitidus. If $G$. truncatula is well known for its passive and active migrations (Moens 1982, for example) and could colonize new habitats in the field (Moens 1991), there was little information on the characteristics of these new communities and the first aim of this note was to report the details of snail settlement for these new populations of $G$. truncatula and their outcome over time. The second aim concerned the role of G. truncatula as an intermediate host in the life cycle of Fasciola hepatica Linnaeus and it was necessary to determine if the susceptibility of these new lymnaeid communities to experimental infections with this trematode didnot differ from that recorded in the populations of origin.

\section{2.:Material and methods:}

'Thřeé pòpùiàtiòns' óf $G$. truncatula, each living in a swampy meadow located in the north of the departmeht of frautel-Vienne, were chosen for the collection of snail samples These populations were known for their high susceptibility to $F$, hepatica infections ( $>60 \%$ when their snails were experimentally subjected to bimiracidial exposures (Rondelaud \& Dreyfuss 1997 , for example). A total of 5.1 samples, each comprising 100 adult snails, were collected from these three populations. Each sample was introduced in March (1976, 1978, 1979 or 1980) in an open drainage furrow (36: meadows) or a road ditch (15 sites) which had never been inhabited by snails. These 51 sites were located on granite soils, within a radius of $5 \mathrm{~km}$ around Limoges and were covered with slowrunning water ( $\mathrm{pH}$ 5.8-7.0) from November to the end of June.

The counting of progeny snails in each new population was performed over a 10 year period after the introduction of the snail sample. Every year, three snail counts (first in March, second in May, third in September) were realized. The method used to count snails in their habitats had already been described (VareilleMorel et al. 1999). The first parameter studied was the number of overwintering snails noted in March in each new population. The two other parameters were the numbers of spring-born snails produced by each overwintering G. truncatula in May and in September, respectively, as these snails belonged to the same springborn generation. Mean values and standard deviations were calculated, taking into account the year post-introduction (the three parameters) and the type of habitat (the first parameter). One-way analysis of variance (Stat-Itcf 1988) was used to establish levels of significance.

Experimental infections of $G$. truncatula with $F$. hepatica were also performed on the twentieth year after the date of snail introduction in new habitats. One hundred preadult snails (shell height, $4 \mathrm{~mm}$ ) were collected from each new colony or each population of origin. Eggs of $\dot{F}$ : hepatica originated from the gall bladders of local and heavily infected cattle. Each snail 'was subjected to a bimiracidial exposure.for 4 hours. After exposure, the snails were subsequently raised for 30 days in:open breeding boxes' (Abrous et al. 1998) under constant conditions of ambient temperature $\left(20^{\circ}\right.$ C) and photoperiod (12/12 hours): At day 30 post-exposurer (p.e. $)$, the surviving snails were dissected under a stereomicroscope to find any larval forms of $F$. hepatica inside their bodies. The two parameters studied 
were the survival rate of snails at day 30 p.e. and the prevalence of experimental infections (calculated using the ratio between the number of snails harbouring larval forms of $F$. hepatica and that of surviving snails at day 30 p.e.). Comparison test of experimental frequencies and one-way analysis of variance (StatItcf 1988) were used.

\section{Results}

\subsection{Outcome of snail samples introduced in new habitats}

In 27 open drainage furrows, located in the hygrophilous areas of meadows, the new colonies had not survived because of the presence of $Z$. nitidus. Indeed, several field investigations performed at the onset of the first summer drying (at the end of June) have revealed that the $G$. truncatula introduced and their progeny were eating by the zonitid snails. Conversely, in the nine other habitats, each situated at the source of a spring just beside the hygrophilous area of the meadow, the introduction of each snail sample had resulted in the development of a new population of $G$. truncatula. An inverse finding was noted in road ditches. New populations of snails had developed in 13 ditches, whereas in the two others, the snails introduced had not survived (presence of $Z$ : nitidus : 1 site, unknown cause : 1 site).

Figure 1 shows the mean numerical variations of overwintering snails throughout a 10 -year period after the introduction of snail samples in new habitats. The numbers of snails peaked on the second year in open drainage furrows (a mean of 244 snails at this date, Fig. 1a) or on the third year in road ditches (631 snails, Fig. 1b). They progressively decreased in the following years to become stable from the sixth or seventh year (less than 40 overwintering snails per site). Comparison of mean values recorded during the four last years (from year 7 to year 10) in the former and latter sites did not demontrate any significant difference.

As the numbers of overwintering G. truncatula in open drainage furrows and road ditches varied in the same way, the values recorded for spring-born snails (Fig. 2) were calculated for each overwintering snail and did not take into account the type of habitat. The mean numbers of spring-born snails ranged from 6.4 to 8.5 in May (Fig. 2a) and did not show any significant variation over the 10 -year period. However, the summer drying of habitats and the predation by $Z$. nitidus reduced these numbers to $0.7-1.4$ snails (per overwintering G: truncatula) in September (Fig. 2b). No significant differences between these mean values were noted over the 10-year period.

\subsection{Experimental infections of snails with $F$. hepati- ca}

The results shown in Table 1 concerned the 22 new colonies of $G$. truncatula and the three populations of origin. In 13 groups of snails ( 8 from open drainage furrows and 5 from road ditches), bimiracidial infec-

\footnotetext{
Table 1. The survival rates of snails at day 30 post-exposure and the prevalences of infections in Galba truncatula, originating from 25 populations and experimentally subjected to individual bimiracidial exposures with Fasciola hepatica.

Tableau 1. Le taux d̊̉ survie des limnées au $30^{\mathrm{e}}$ jour post-exposition et la prévalence de l'infestation chez 25 populations de Galba truncatula lorsqu'elles sont soumises à des expositions bimiracidiennes individuelles aveć Fasciola hepatica.
}

\begin{tabular}{lccc}
\hline & $\begin{array}{c}\text { Number of snail groups } \\
\text { subjected to miracidial } \\
\text { exposures }\end{array}$ & $\begin{array}{c}\text { Range of } \\
\text { survival rates (\%) } \\
\text { at day 30 p.e. }\end{array}$ & $\begin{array}{c}\text { Range of prevalences } \\
\text { for infections (\%) } \\
\text { at day } 30 \text { p.e. }\end{array}$ \\
\hline $\begin{array}{l}\text { Populations of } \\
\text { origin }\end{array}$ & 3 & $53.0-62.0$ & $71.6-77.2$ \\
$\begin{array}{l}\text { Open drainage } \\
\text { furrows }\end{array}$ & 8 & $48.0-65.0$ & $68.7-81.3$ \\
& 1 & 53.0 & 33.9 \\
Road ditches & 5 & $52.0-61.0$ & $66.2-77.9$ \\
\hline
\end{tabular}



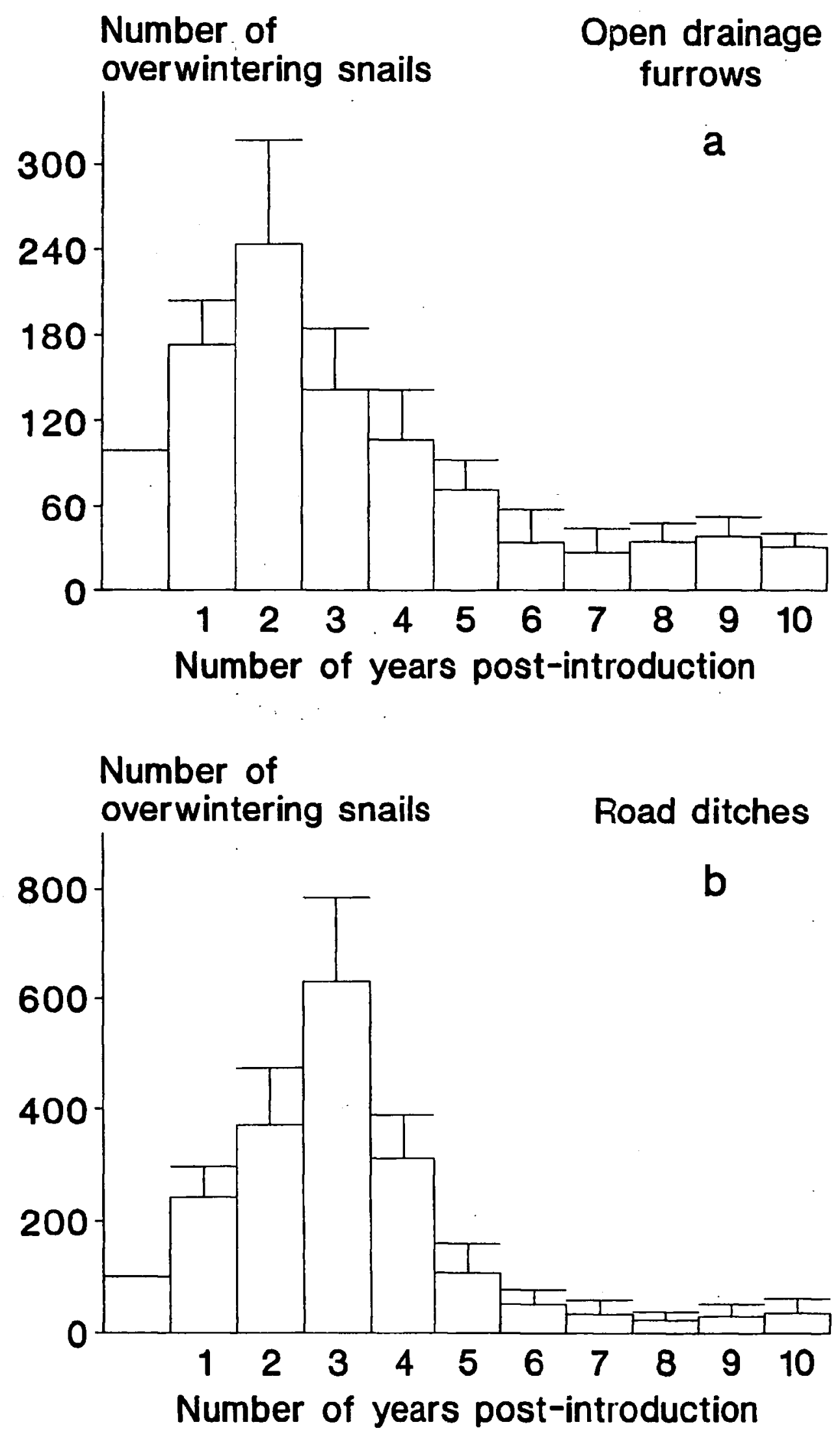

Fig. 1. Mean values and SD for the number of overwintering Galba truncatula counted in March over a 10-year period : open drainage furrows ( 1 a) and road ditches (1b).

Fig. 1. Valeurs moyennes et écarts-types pour le nombre de Galba truncatula transhivernantes, comptées en mars pendant 10 années : rigoles de drainage superficiel (la) et fossés de route (1b). 

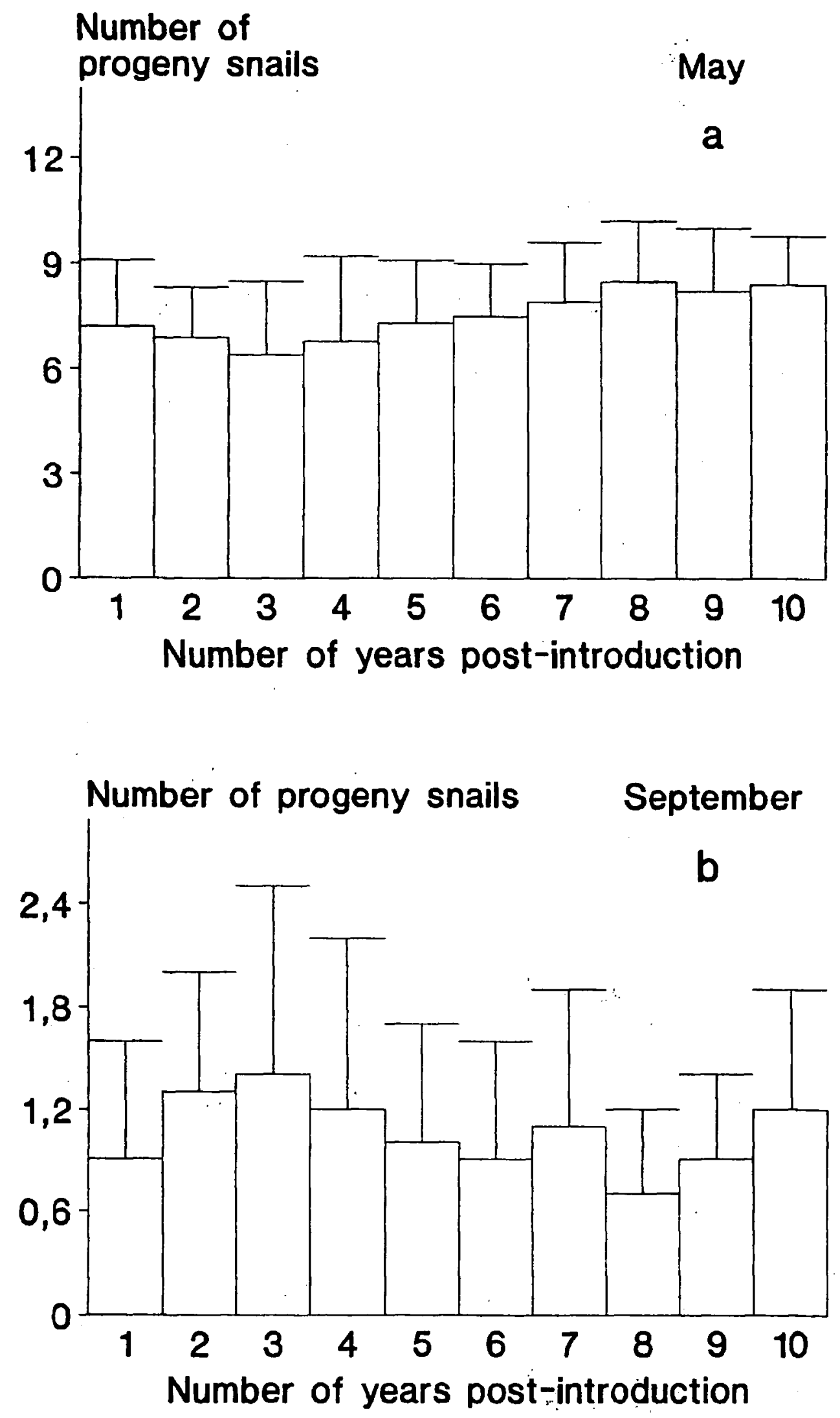

Fig. 2. Mean values and SD for the number of spring-born Galba truncatula (for each overwintering snail) in May (2a) and in September (2b). The results noted in open drainage furrows and road ditches were pooled .

Fig. 2. Valeurs moyennes et écarts-types pour le nombre de Galba truncatula nées au printemps et décomptées en mai (2a), puis en septembre (2b). Les résultats des rigoles de drainage et ceux des fossés de routes ont été regroupés.Ils sont présentés en tenant compte du nombre des limnées transhivernantes. 
tions of snails did not demonstrate any significant differences in the survival rates or in the prevalences of infections when compared to the respective rates recorded in the three populations of origin. Conversely, in the nine other groups, the prevalences of infections were significantly $\left(F_{1.23}=9.67, P<0.01\right)$ decreased when compared to the infection rates recorded in the three populations of origin, whereas the survival rates of snails at day 30 post-exposure did not change.

\section{Discussion}

In each of the 22 new habitats, the introduction of $G$. truncatula resulted in an increase of snail numbers up to the second or third year, followed by a decrease in the subsequent years. If the high fecundity of $G$. truncatula (Kendall 1953) and its ability to rapidly populate new habitats (Taylor 1964) could explain the numerical increases of snails found in the furrows and ditches during the first years post-introduction, they could not be used to interpret the low numbers of snails found in these sites from the sixth or seventh year. To comment this last finding, the most valid hypothesis would be to admit that the number of snails in each habitat would be progressively regulated by biotic and/or environmental factors, and that this regulation would only begin on the second or third year following snail introduction. Under these circumstances, the furrows and ditches colonized by these new populations might finally be considered as reservoir habitats (Taylor 1964) in which unsuitable conditions could maintain the populations of $G_{i}$ truncatula at low and constant densities.

More surprising were the low prevalences of Fasciola infections ( $<40.0 \%$, see Table 1$)$, noted in nine samples of snails, whereas their survival rates at day 30 p.e. were similar to those found in the 16 other samples of infected snails. This finding is more difficult to interpret. As the exposures of these 25 snail samples to $F$. hepatica were performed with the same strains of miracidia (a single isolate of miracidia per year), the origin of parasite and, consequently, its infectivity might not be involved to explain these low prevalences of infections in nine groups of snails. The most valid hypothesis would be to admit these last results can result of changes in natural parasite pressure in the nine new snail habitats and that this pressure is probably lower than that existing in the three sites in- habited by the populations of origin. This assumption was supported by the report of Rondelaud \& Dreyfuss (1998) on French Stagnicola glaber. According to these authors, if experimental infections of $S$. glaber with $F$. hepatica were every year performed using snails collected from wild watercress bed, the prevalences of these infections did not change in the time, whereas in the snails from the same geographic origin but maintained in a laboratory breeding during several successive years, the rates of infections in snails decreased throughout successive years, whatever the shell height of snails at miracidial exposure. This result indicated that the susceptibility of this $S$. glaber population to the parasite would not be permanent in the field and would progressively disappear after some y'ears when the natural encounter between snails and parasite did not occur.

$r$

\section{References}

Abrous M., Roumieux L., Dreyfuss G., Rondelaud D. \&-Mage C. 1998. - Proposition d'une technique simple pour la production métacercarienne de Fasciola hepatica Linné à partir du mollusque Lymnaea truncatula Müller. Rev. Méd. Vèt., 149: 943-948.

Kendall S.B. 1953. - The life-history of Limnaea truncatula under laboratory conditions. J. Helminthol., 27 : 17-28.

- Moens R. 1982. - Mécanisme de réinfestation par Lymnaea truncatula Müllíer (Mollusca Pulmonata) des terrains propices à la fasciolose. Malacologia, $22: 29-34$.

Moens R. 1991. - Factors affecting Lymnaea truncatula populations and related control measures. J. Med. Appl. Malacol., 3 : 73-84.

Rondelaud D. 1975. - La'prédatión de Lymnaea (Galba) truncatula Müller par Zonitoides nitidus Müller, moyen de lutte biologique. Anns Parasitol. Hum. Comp', 50 : 55-61.

-Rondelaud D. 1981. - Le contrôle biologique de 'Lymnaéa truncatula Müller. Bilan d'une expérimentation de neuf années en Haute-Vienne, France. Haliotis, $11: 213-224$.

Rondelaud D. \& Dreyfuss G. 1997. - Variability of Fasciola infection in Lymnaea truncatula as a function of snail generation and snail activity. J:Helminthol;, $71: 161-166$.

Rondelaud D. \& Dreyfuss G. 1998. - L'infestation naturelle de Lymnaea glabra par Fasciola hepatica dans deux cressonnières naturelles de la Haute-Vienne. Bull. Soc. Fr. Parasitol., 16 : 291-297.

Stat-Itcf. 1988. - Manuel d'utilisation. Institut technique des céréales et des fourrages, Service des études statistiques, Boigneville, France : $210 \mathrm{p}$.

Taylor E.L. 1964. - Fascioliasis and the liver fluke. FAO agricultural studies, Roma, Italy, $\mathrm{n}^{\circ} 64: 234 \mathrm{p}$.

Vareille-Morel C., Dreyfuss G. \& Rondelaud D. 1999. - The characteristics of habitats colonized by three species of Lymnaea (Mollusca) in swampy meadows on acid soil : their interest for control of fasciolosis. Ann. Limnol.; 35 : 173-178. 